\title{
Hvile etter hjernerystelse?
}

\begin{abstract}
$\AA$ A hvile i fem dager gir ikke raskere bedring enn gradvis å gjenoppta normale aktiviteter etter hjernerystelse.
\end{abstract}

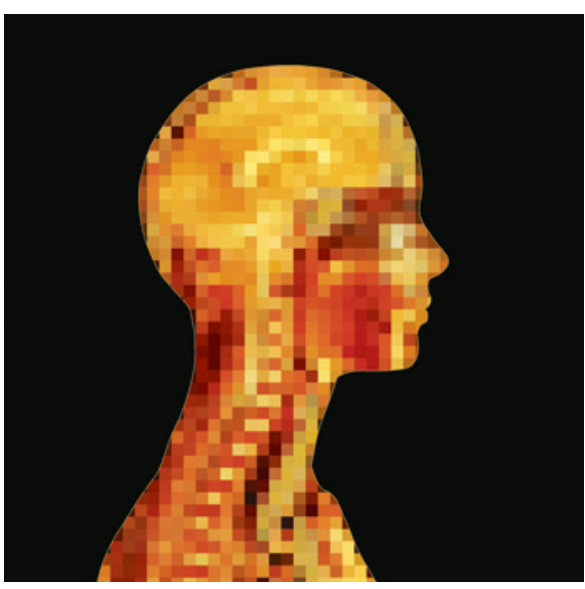

Illustrasjonsfoto: Science Photo Library
Det er vanlig å anbefale hvile til pasienter som har hatt hjernerystelse, men har det egentlig effekt? I en studie som nylig ble publisert i tidsskriftet Pediatrics, undersøkte man hva som er best: hvile i flere dager eller gradvis gjenopptakelse av vanlige aktiviteter (1).

Pasientene var fra 11 til 22 år gamle og var alle blitt behandlet ved et akuttmottak pga. hjernerystelse i løpet av siste døgn. Av 88 pasienter som fullførte hele studien, var 45 randomisert til hvile i fem dager og 43 til hvile i én til to dager og deretter gradvis gjenopptakelse av normale aktiviteter. Pasientene førte dagbok med registrering av fysisk aktivitet, mental aktivitet og symptomer.

Det var ingen signifikante forskjeller mellom gruppene ved nevrokognitive tester og balansetester tre og ti dager etter skaden. Pasientene som fikk hvile i fem dager, rapporterte signifikant mer daglige symptomer, og det tok lengre tid før symptomene gikk over, enn gruppen som ble anbefalt gradvis å gjenoppta aktiviteter.

- Studiens viktigste funn er at den praksis vi har ved de fleste sykehus i landet, dvs. et par dagers hvile og deretter en gradvis mobilisering, styrt av pasienten selv, virker trygt og fornuftig, sier Ola-Lars Hammer, som er seksjonsoverlege ved Skadekirurgisk legevakt, Akershus universitetssykehus.

- Det er fristende å tro at å anbefale flere hviledager kan bidra til økt sykeliggjøring av pasienter med en ukomplisert skade, sier Hammer.

\section{Lise Mørkved Helsingen}

Tidsskriftet

Litteratur

1. Thomas DG, Apps JN, Hoffmann RG et al. Benefits of strict rest after acute concussion: a randomized controlled trial. Pediatrics 2015; 135: 213-23.

\section{Bør flere ungdommer få statiner?}

\section{Ifølge amerikanske retningslinjer bør flere barn og ungdommer med høyt kolesterolnivå vurderes for statinbehandling.}

I USA finnes det egne retningslinjer for statinbehandling for henholdsvis voksne og barn/ungdommer. I perioden 1999-2012 deltok rundt 6000 ungdommer $\mathrm{i}$ alderen 17-21 år i en surveyundersøkelse for å kartlegge indikasjoner for medikamentell behandling av forhøyede nivåer av LDL-kolesterol (1). Retningslinjene for voksne tilsa at $0,4 \%(95 \%$ KI 0,1-0,8) av dem mellom 17 til 21 år var aktuelle for statinbehandling, mens retningslinjene for barn og ungdommer tilsa at $2,5 \%(1,8-3,2)$ var aktuelle for statinbehandling. Dette innebærer at flere enn 400000 ungdommer bør vurderes for statinbehandling.

- Retningslinjene for barn og ungdommer som ble brukt i denne studien, har en algoritme som tar hensyn til LDL-kolesterol, diabetes, overvekt, røyking, hypertensjon og familiehistorie med hjertesykdom, sier Leiv Ose, professor emeritus ved Avdeling for ernæringsvitenskap, Institutt for medisinske basalfag, Universitet i Oslo.
- Det vil være en diskusjon om langtidsbehandling med statiner fra ungdomsalder er veien å gå. Det finnes ikke tilsvarende norske retningslinjer for ungdommer, og det er vanskelig å bruke den anvendte algoritmen for ungdommer i Norge. Vi savner også data for risikofaktorer hos barn og ungdommer for å si noe om hvor stort problemet eventuelt vil være, sier Ose.

\section{Tor Atle Rosness}

Tidsskriftet

\footnotetext{
Litteratur

1. Gooding HC, Rodday AM, Wong JB al. Application of pediatric and adult guidelines for treatment of lipid levels among US adolescents transitioning to young adulthood. JAMA Pediatr. E-publisert 6.4.2015.
}

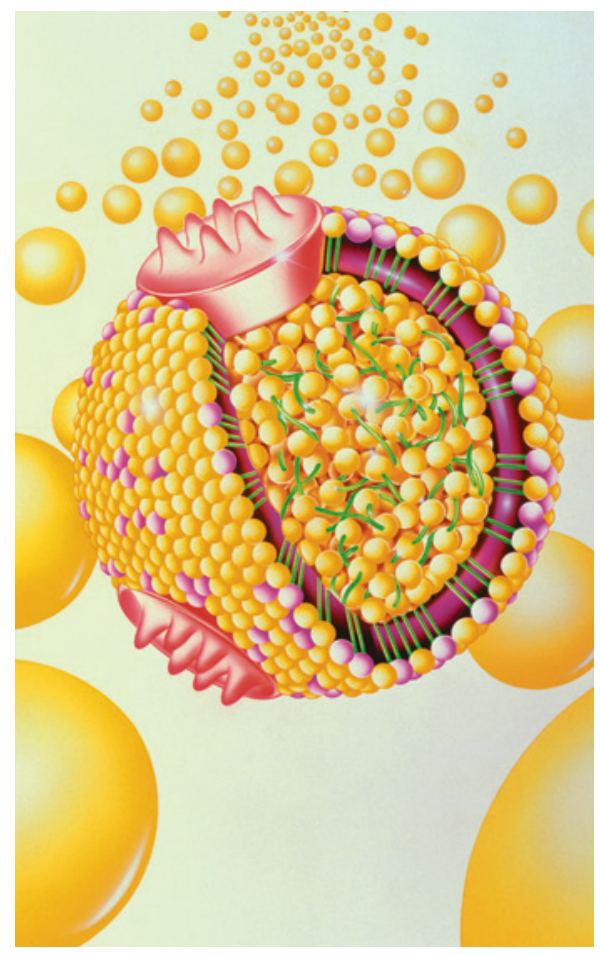

Illustrasjonsfoto: Science Photo Library 